to be found in Neolithic times in north-western Europe.

The portraits of the West Greenland type show that they approximate much more closely to the European type. These people live much further south, on the tracts of land left between the margin of the great Greenland glacier and the west coast. The West Greenlanders appear to have abundant supplies of food, obtained by hunting and fishing, walrus, seal, halibut, and salmon in the greatest abundance being readily obtainable by the active native. They are very hospitable and superstitious, the latter trait, according to the author, being due to the influence of the long winter night.

The East Greenlanders have now mostly migrated

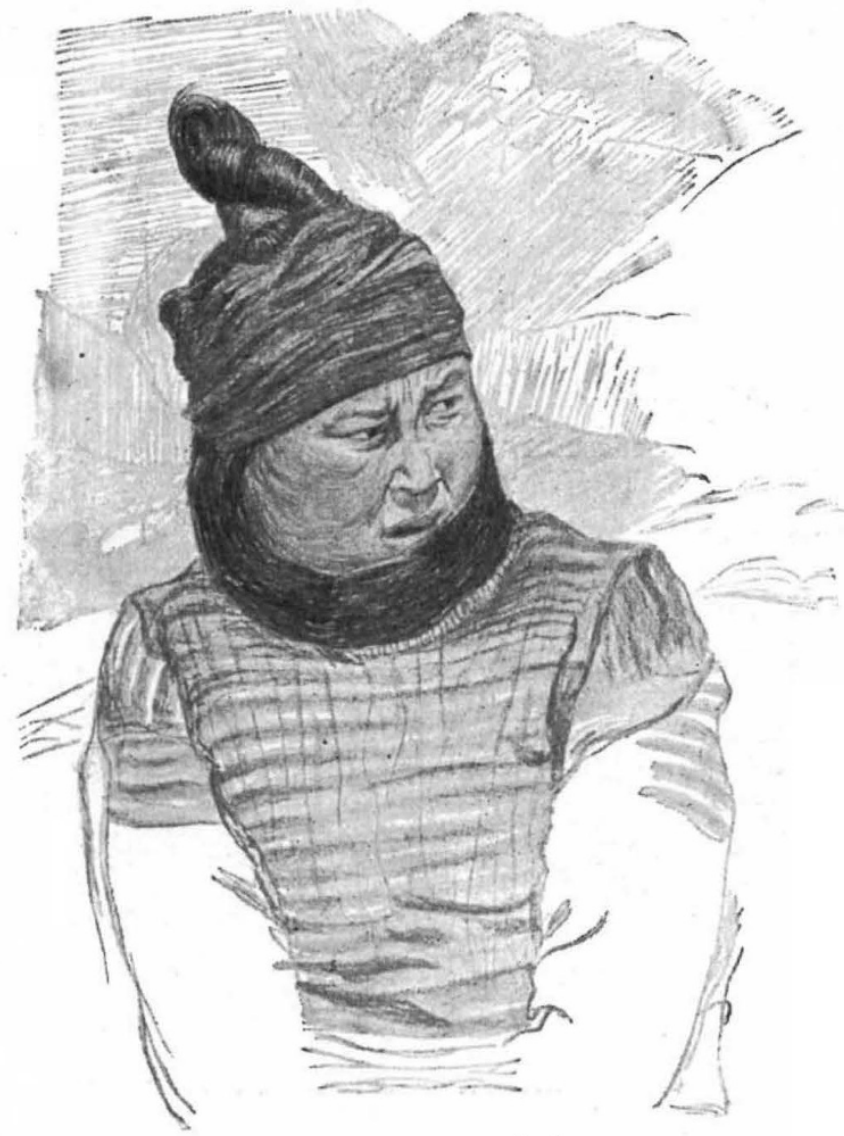

FIG. 2.-Greenlandic Woman from Kangeq, near Godthaab. From "The People of the Polar North."

from the east coast to West Greenland. Apparently, before they moved, owing to their isolation they had reverted to a state of savagery and developed a kind of murderous mania which led to the most terrible tragedies. Now, when living amongst the West Greenlanders, they appear to have greatly advanced under the influence of the Danish missionaries.

The map attached to the volume would be of much greater value if it contained more of the places referred to in the text.

This book, however, will take a high place as a study of the characteristics of an extremely interesting and fast vanishing people by a competent and sympathetic observer.

NO. 2046, VOL. 79]

\section{A HUMAN FOSSIL FROM THE DORDOGNE} $V A L L E Y$.

THE curtain which conceals the early history of our race is being in these last years lifted at frequent intervals to afford us glimpses into the distant past. Among the latest revelations are those by the Swiss explorer, M. Hauser, of a nearly complete human skeleton-not yet fully described-from a rock-shelter in the Vézère Valley, chinless, with the great orbits and retreating forehead characteristic of the Neanderthal type; and those still more recently made by the well-known prehistorians the Abbés J. and A. Bouyssonie and M. L. Bardon during their excavation of a cave opening in the vale of a small tributary of the Dordogne river, in the commune of La Chapelle-aux-Saints, in the Corrèze. Their careful and scientifically conducted excavations had previously, in 1905 , been rewarded by the discovery of numerous quartz and jasperoid flint implements, scrapers (racloirs) and lance-heads (pointes), with others rather better finished and suggestive of the Aurignacian, which, taken with the entire absence of ruder amygdaloid implements (coups de poing) and of all worked bone, fixes with precision the archæological horizon as Late Mousterian. The fauna associated with these industrial relics includes reindeer, horse (rare), badger, woolly rhinoceros, marmot, wolf, fox, sheep or goat, a large bovine, and birds, and is characteristic of the cold climate of that epoch, which corresponds, in geological terms, to the Middle Pleistocene.

During last autumn the same three archæologists resumed their investigations, with the result that on August 3, while digging a trench in the cave, they uncovered a human skeleton, lying on its back, with the head, which was protected by stones, directed to the east. The right arm was bent so that the hand lay towards the body, the left arm was slightly extended, and the limbs were drawn up. Above the head were several large fragments of bone laid flat, while near by was placed the terminal phalanges of the hind hoof, with several of its associated bones, of a large bovine. The body was, therefore, intentionally buried, and as there is an entire absence of fireplaces it is concluded by the excavators, but probably not with universal accord, that the cave was not used as a dwelling, but only as a burying-place, where the abundance of bones and implements indicate only the holding of numerous funeral-feasts.

These human remains, which are of the greatest anthropological importance and interest, have been described by M. MarBoule, the distinguished palæontologist, in a preliminary note read on December 14 last before the French Academy of Sciences, and published in the Comptes rendus of the academy cited below. The bones comprise a much broken cranium and mandible, vertebræ and limb-bones of a man of $r^{\circ} 60 m$. (a little more than 5 feet 2 inches) in stature. As the edges of the cranial fragments were unworn, it was possible to piece them very accurately together. The

1 "L'Homme fossile de la Chapelle-aux-Saints (Corrèze)." Ňote de M. Marcellin Boule (Comptes rendus de l'Académie des Sciences, t. cxlvii., No. 24. December 14, 1908).

"Découverte d'un squelette II umain mousterien à La Chapelle-aux-Saints (Corrèze)." Note de MM. A. and J. Bourssonie et L. Bardon (Comptes rendus, t. cxlvii., No. 25, Decenber 21, 1908). 
eranium, from the state of its sutures and its dentition that of an aged male, is remarkable for its size in comparison with the short stature of its owner, and for its simian or pithecoid characters. The skull is dolichocephalous (index 75), and remarkable for its thick bones, its flattened cranial vault, enormous browridges (which are more prominent than in the original Neanderthal cranium), with a deep groove above them stretching from one orbital process to the other, for its much depressed occipital "bulging," for the backward position of the foramen magnum, the flattening of the occipital condyles, and the feeble development of the mastoid processes. The very prognathous face has large and prominent orbits, with a deep depression between them separating the short and very broad nose from the forehead. The upper maxillary differs widely from that in all living races of mankind, in projecting in front, into a sort of muzzle; while the palatine contour is very simian. The lower jaw is remarkable for its massiveness, the great width of its condyle, the shallowness of its sigmoid notch, the obliquity of its symphysis, and the absence of chin.

The La Chapelle-aux-Saints cranium, therefore, presents the characters, in some respects exaggerated, which distinguish the Neanderthal and Spy calvaria, all of which, though widely spread over Europe, but on about the same geological horizon, certainly belong, in M. Boule's opinion, to one type. Its mandible also presents the characters of the fossil mandibles, of the same age, known as Naulette, Spy, and Malarnaud. In the same palæontologist's estimation, the Neanderthal type should be considered a normal human tvpe, characteristic of certain parts of Europe in the Middle Pleistocene. This type is different from, and lower than, any now living, for in no existing race are to be found united the low characters seen in the La Chapelle-aux-Saints cranium.

M. Boule, however, is not prepared to separate the Neanderthal-Spy-La Chapelle-aux-Saints group generically, but he would not hesitate to distinguish the La Chapelle-au-Saints man specifically from those of all other human groups, living or fossil. He considers it certain that the Neanderthal-Spy-La Chapelleaux-Saints group represents a low type, nearer to the anthropoid apes than to any human group, and morphologically he would place them between Pithecanthropus and the lowest living races, yet without implying that they are in the same genetic line. The men of the Middle Pleistocene, judged by their physical characters and the relics of their industry, were in a primitive condition intellectually; while those who lived during the Upper Pleistocene possessed mental powers of a much higher order and were capable of producing true works of art, and their crania acquired the principal characters-the fine forehead, large brain, heaven-surveying countenance-of Homo sapiens.

A special interest attaches to the description given above of this new type of Homo, when we recall the various drawings of supposed "humans" left us by the men of the Upper Pleistocene on reindeer horn, ivory, and fragments of schist. These artists have depicted for us an extensive zoological picture-gallery, with a fidelity to nature hardly to be surpassed by any present-day artist. Their sketches are all from subjects with which they were intimately acquainted, and if there be forms among them which so far have not been recognised by us, we may rest assured that they were also reproduced from actual models. Among the palæolithic engravings much criticised are those of various anthropoid forms-such as the two accompanying examples (Figs. I and 2) from M. Piette and MM. Cartailhac and Breuil-which some ethnologists have hesitated to recognise as human, because of their pronounced simian characters.

The description given above of the man of La Chapelle-aux-Saints seems tor fit, in his snout-like jaws; semi-erect attitude, gibbonlike nose (especially Fig. 2), with wonderful exactitude, the drawings preserved to us at Mas d'Azil and elsewhere. Two very interesting questions suggest themselves: Are these pictures of a race surviving from the Middle Pleistocene? and, Were the artists of the Reindeer age depicting individuals of their own race? The present writer is convinced, and has long held, that they certainly depicted people contemporaneous with themselves, and reproduced them

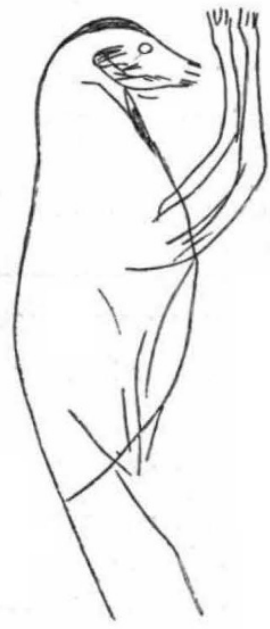

FIG. I.

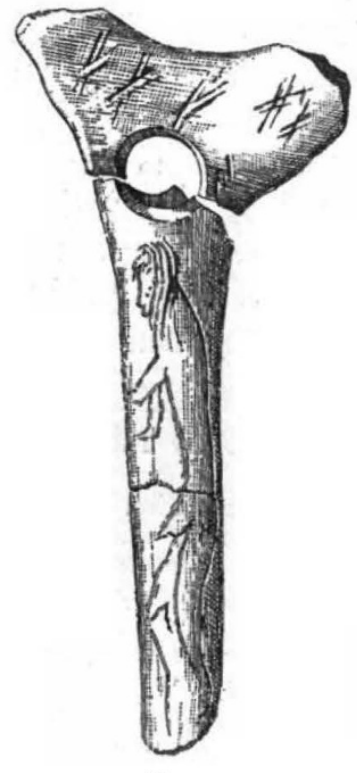

FrG. 2. as accurately as they did the bisons, horses, and rhinoceroses amid which they lived.

H. O. F.

\section{BLACK-WATER FEVER.'}

WE have before us a very careful and detailed study of one of the most dangerous of tropical diseases, which has numbered many victims amongst Europeans of all ranks and classes in various parts of the world; the public that reads Nature will not need to be reminded of the sad death of that distinguished zoologist, Mr. J. S. Budgett, from blackwater consequent on malaria contracted during his collecting expeditions in Africa.

The authors are especially concerned with the question of the nature and origin of black-water fever; the prophylaxis and treatment of the disease are dealt with very briefly. After a historical introduction the etiology of black-water fever is discussed and narrowed down to two alternative hypotheses, (I) that the disease is due to a specific organism, (2) that it is of malarial origin. It is then shown that the disease is not due to any parasite visible to critical microscopical examination, and that " the trend of evidence is steadily in favour of a malarial, as against a specific, origin." Facts are brought forward to show that in black-water fever the process of blooddestruction is what the authors propose to call "lysæmia," namely, "that condition, in which the red cells undergo solution in the plasma, and in which 1 "Black.water Fever." By S. R. Christophers and C. A. Bentley. Scientific Memoirs by Officers of the Medical and Sanitary Departments of the Government of India, No. 35. Pp. iv +239 . 